\title{
Konsep Perumahan Sehat Berwawasan Lingkungan ( siberling ) pada zona aliran sungai
}

\author{
Asriadi Asriadi $^{1)}$, Agung Pamudjianto ${ }^{2)}$ \\ 1), 2) Program Studi Teknik Sipil Universitas Muhammadiyah Sorong \\ Jl Pendidikan No 27 Kota Sorong \\ Email : asriadisoq89@gmail.com
}

1. Permukiman

\subsection{Konsep Permukiman}

Pengertian dasar permukiman dalam Undang-Undang No.1 tahun 2011 adalah bagian dari lingkungan hunian yang terdiri atas lebih dari satu satuan perumahan yang mempunyai prasarana, sarana, utilitas umum, serta mempunyai penunjang kegiatan fungsi lain dikawasan perkotaan atau kawasan perdesaan.

Menurut Koestoer (1995) batasan permukiman adalah terkait erat dengan konsep lingkungan hidup dan penataan ruang. Permukiman adalah area tanah yang digunakan sebagai lingkungan tempat tinggal atau lingkungan hunian dan tempat kegiatan yang mendukung peri kehidupan dan merupakan bagian dari lingkungan hidup di luar kawasaan lindung baik yang berupa kawasan perkotaan maupun perdesaan. Parwata (2004) menyatakan bahwa permukiman adalah suatu tempat bermukim manusia yang telah disiapkan secara matang dan menunjukkan suatu tujuan yang jelas, sehingga memberikan kenyamanan kepada penghuninya. Permukiman (Settlement) merupakan suatu proses seseorang mencapai dan menetap pada suatu daerah (Van der Zee 1986). Kegunaan dari sebuah permukiman adalah tidak hanya untuk menyediakan tempat tinggal dan melindungi tempat bekerja tetapi juga menyediakan fasilitas untuk pelayanan, komunikasi, pendidikan dan rekreasi.

\subsection{Bentuk-bentuk Permukiman}

Sebuah permukiman terbentuk dari komponen-komponen dasar yaitu:

(1) rumah-rumah dan tanah beserta rumah.

(2) tanah kapling rumah dan ruang tanah beserta rumah.

(3) tapak rumah dan perkarangan rumah

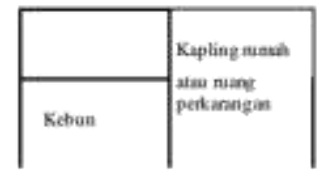

a.Tanah kapling rumah atau perkarangan

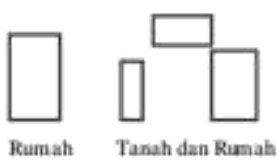

b. Rumah dan struktur lainya

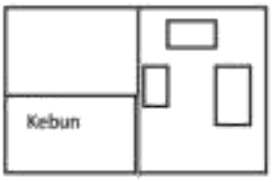

c.Perkarangan rumah 
Perkarangan rumah atau tempat-tempat rumah biasanya disusun dalam kelompok yang homogen dalam segi bentuk, fungsi, ukuran, asal mula dan susunan spasial. Dua atau lebih kelompok-kelompok dapat membentuk sebuah komplek. Bentuk dari permukiman dinyatakan dalam bentuk tempat dan bentuk perencanaan tanah. Perencanaan tanah dibentuk oleh kelompok-kelompok dan komplek-komplek dari tempat rumah dan perkarangan rumah.

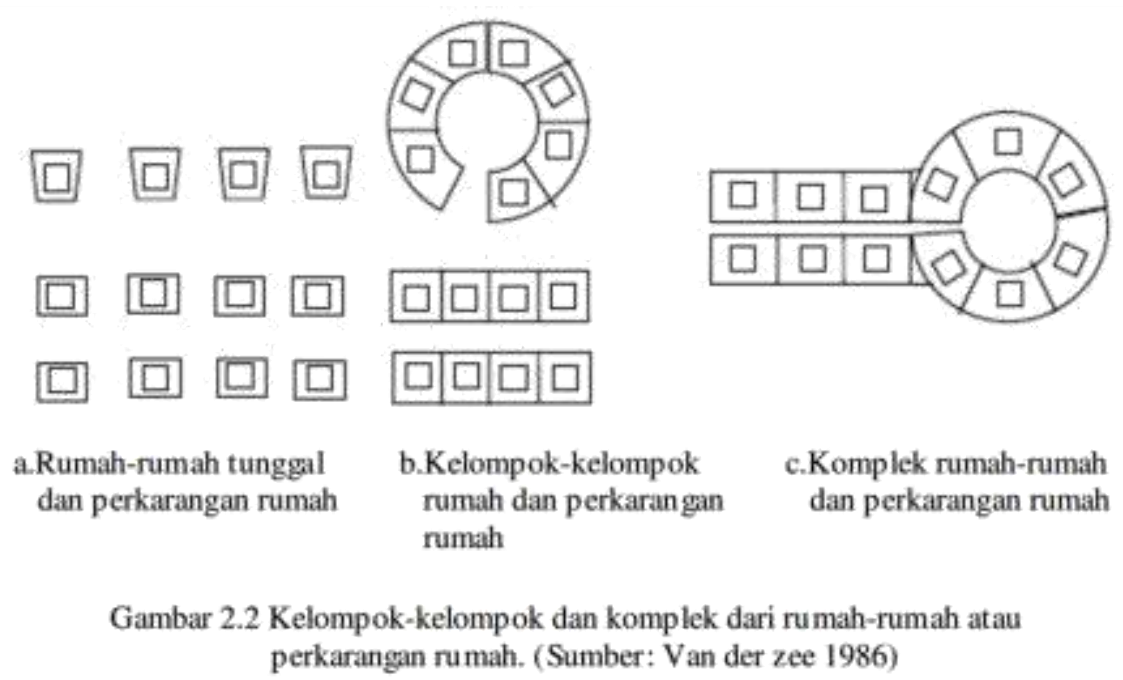

\subsection{Pola Penyebaran Pembangunan Perumahan dan Permukiman}

Pola penyebaran pembangunan perumahan dan permukiman di wilayah desa kota menurut Koestoer (1995), pembentukannya berakar dari pola campuran antara ciri perkotaan dan perdesaan. Ada perbedaan mendasar pola pembangunan permukiman di perkotaan dan perdesaan. Wilayah permukiman di perkotaan sering disebut sebagai daerah perumahan, memiliki keteraturan bentuk secara fisik. Artinya sebagian besar rumah menghadap secara teratur ke arah kerangka jalan yang ada dan sebagian besar terdiri dari bangunan permanen, berdinding tembok dan dilengkapi dengan penerangan listrik. Kerangka jalannya pun ditata secara bertingkat mulai dari jalan raya, penghubung hingga jalan lingkungan atau lokal.

\section{Pekarangan}

Pekarangan adalah sebidang tanah darat yang terletak langsung di sekitar rumah tinggal dan jelas batas-batasannya, ditanami dengan satu atau berbagai jenis tanaman dan masih mempunyai hubungan pemilikan dan/atau fungsional dengan rumah yang bersangkutan. Hubungan fungsional yang dimaksudkan di sini adalah meliputi hubungan sosial budaya, hubungan ekonomi, serta hubungan biofisika. Hasil penelitian pekarangan yang dilakukan Arifin, Sakamoto \& Chiba (1998) menunjukkan bahwa semakin ke hilir rataan area RTH pekarangan dan penutupan kanopi tanaman semakin luas. Rataan jumlah species tanaman per pekarangan pun semakin besar. Hasil penelitian berikutnya menunjukkan keragaman vertikal didasarkan pada kehadiran stratifikasi tanaman mulai 
dari rerumputan, herba, semak, perdu, liana dan pohon tinggi. Selanjutnya hasil penelitian Arifin (1998) menunjukkan strata tanaman yang tumbuh dipekarangan meliputi 5 klas, yaitu :

- $\quad \operatorname{starta} \mathrm{I}(<1 \mathrm{~m})$

- $\quad$ starta II (1-2m)

- $\quad$ strata III $(2-5 \mathrm{~m})$

- $\quad$ strata IV (5-10m) dan strata V (>10m)

\section{Daerah Aliran Sungai ( DAS )}

Daerah aliran sungai (DAS) adalah sebuah kawasan yang dibatasi oleh pemisah topografis yang menampung, menyimpan dan mengalirkan curah hujan yang jatuh di atasnya ke sungai utama yang bermuara ke danau atau lautan. Pemisah topografi adalah punggung bukit dan pemisah bawah berupa batuan (Manan 1983). Sheng (1968) mendefinisikan DAS sebagai suatu kawasan yang mengalirkan air yang jatuh di atasnya ke dalam suatu sistem aliran sungai yang mengalir dari hulu menuju ke muara atau tempat-tempat tertentu. Tempat tertentu tersebut antara lain dapat berupa danau atau lautan. Oleh karena itu batas ekosistem suatu DAS dapat ditentukan berdasarkan perilaku dari aliran airnya. Kawasan tersebut dipisahkan dengan kawasan lainnya oleh pemisah topografi. Di Amerika Serikat daerah bersistem sungai-sungai biasa disebut "watershed" sedangkan di Inggris disebut "cathchment areas of river basin". Dalam istilah pembangunan biasanya disebut river basin development apabila berkaitan dengan pembangunan bendungan dan sistem irigasi, dan watershed apabila berkaitan dengan pembangunan yang berkaitandengan penatagunaan tanah, perlindungan terhadap erosi dan pengelolaan bentang alam (Haeruman 2002).

\section{Rumah Sederhana Sehat (Rs Sehat)}

\subsection{Kebutuhan Minimal Masa (penampilan) dan Ruang (luar-dalam).}

Kebutuhan ruang per orang dihitung berdasarkan aktivitas dasar manusia di dalam rumah. Aktivitas seseorang tersebut meliputi aktivitas tidur, makan, kerja, duduk, mandi, kakus, cuci dan masak serta ruang gerak lainnya. Dari hasil kajian, kebutuhan ruang per orang adalah $9 \mathrm{~m} 2$ dengan perhitungan ketinggian rata-rata langit-langit adalah $2.80 \mathrm{~m}$, contoh kebutuhan luas minimum untuk rumah sederhana sehat adalah $27 \mathrm{~m} 2$.

\subsection{Kebutuhan Kesehatan dan Kenyamanan}

Rumah sebagai tempat tinggal yang memenuhi syarat kesehatan dan kenyamanan dipengaruhi oleh 3 (tiga) aspek, yaitu pencahayaan, penghawaan, serta suhu udara dan kelembaban dalam ruangan. Aspek-aspek tersebut merupakan dasar atau kaidah perencanaan rumah sehat dan nyaman. 
- Pencahayaan

- Penghawaan

- Suhu Udara dan Kelembapan

\subsection{Kebutuhan Minimal Keamanan dan Keselamatan}

Pada dasarnya bagian-bagian struktur pokok untuk bangunan rumah tinggal sederhana adalah: pondasi, dinding (dan kerangka bangunan), atap serta lantai. Sedangkan bagian-bagian lain seperti langit-langit, talang dan sebagainya merupakan estetika struktur bangunan saja.

\section{Elemen Standar Tata Ruang Rumah}

Kendala keterjangkauan masyarakat terhadap Rumah Sederhana Sehat (Rs Sehat), telah diupayakan menyiasati kondisi tersebut melalui satu rancangan rumah antara yaitu RIT (Rumah Inti Tumbuh) sebagai rumah cikal bakal Rumah Sederhana Sehat. Rancangan RIT memenuhi tuntutan kebutuhan paling mendasar dari penghuni untuk mengembangkan rumahnya, dalam upaya peningkatan kualitas kenyamanan, dan kesehatan penghuni dalam melakukan kegiatan hidup sehari-hari, dengan ruang-ruang yang perlu disediakan.

Permukiman SEBERLING di zona hilir DAS yang menempati lahan pada kelas kesesuaian lahan sangat sesuai memiliki kriteria sebagai berikut:

a. Pola permukiman di zona hilir DAS memiliki karakteristik

b. Bangunan rumah memiliki karakteristik.

c. Permukiman harus memiliki sarana pengelolaan lingkungan.

Aspek sosial dari permukiman SEBERLING adalah berupa kelembagaan masyarakat dalam mengelola lingkungan di wilayah DAS Kelembagaan komunitas dibangun berdasarkan kondisi masyarakat yang tinggal di wilayah DAS. Kelembagaan bisa bersifat formal atau informal tergantung pada kebutuhan dan ruang lingkupnya. Kelembagaan ini berada pada setiap unit permukiman terkecil yaitu kampung untuk masing-masing zona DAS. 
Beberapa Contoh

Konsep Perumahan Sehat Berwawasan Lingkungan ( siberling ) pada zona aliran sungai
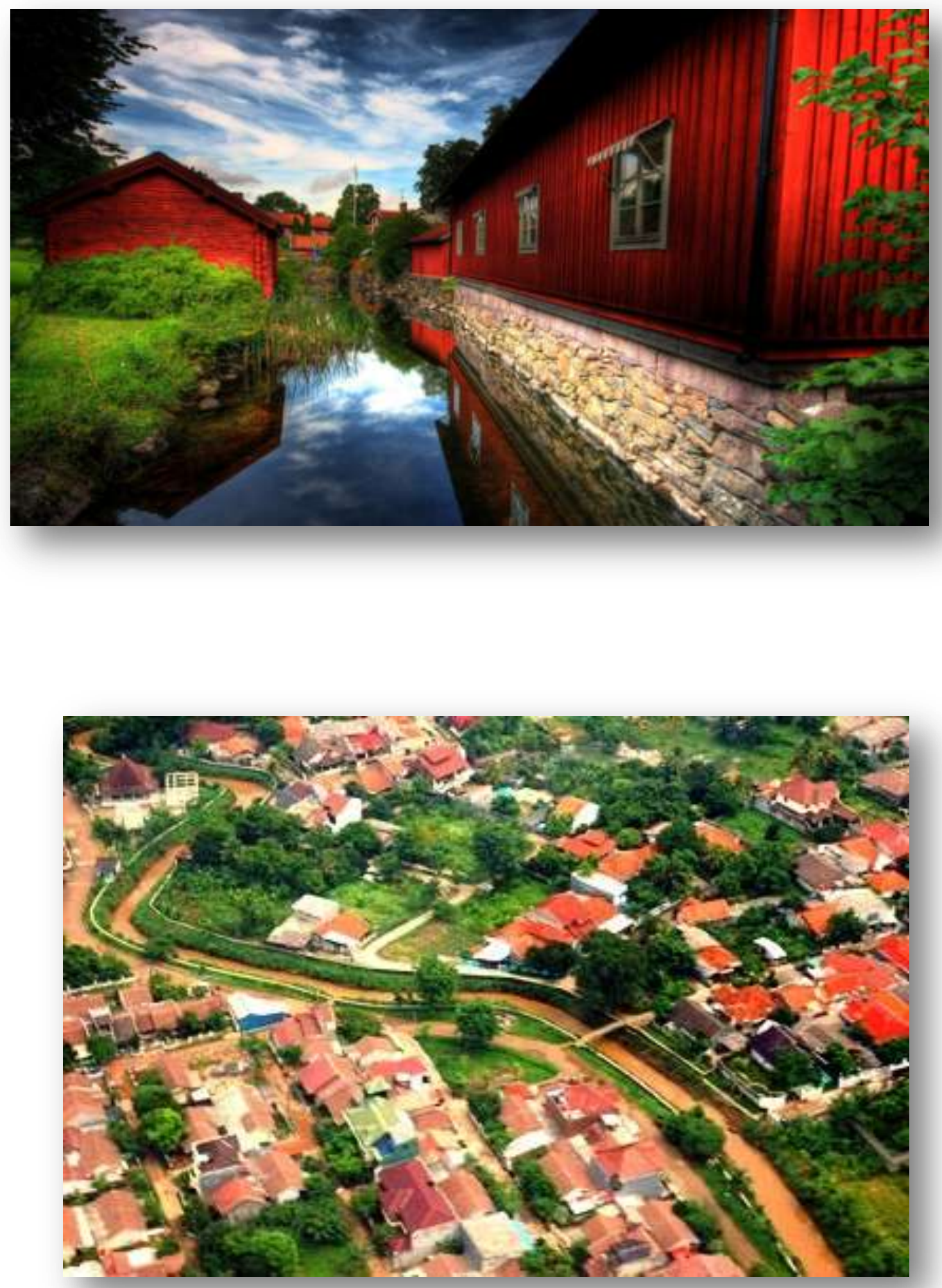


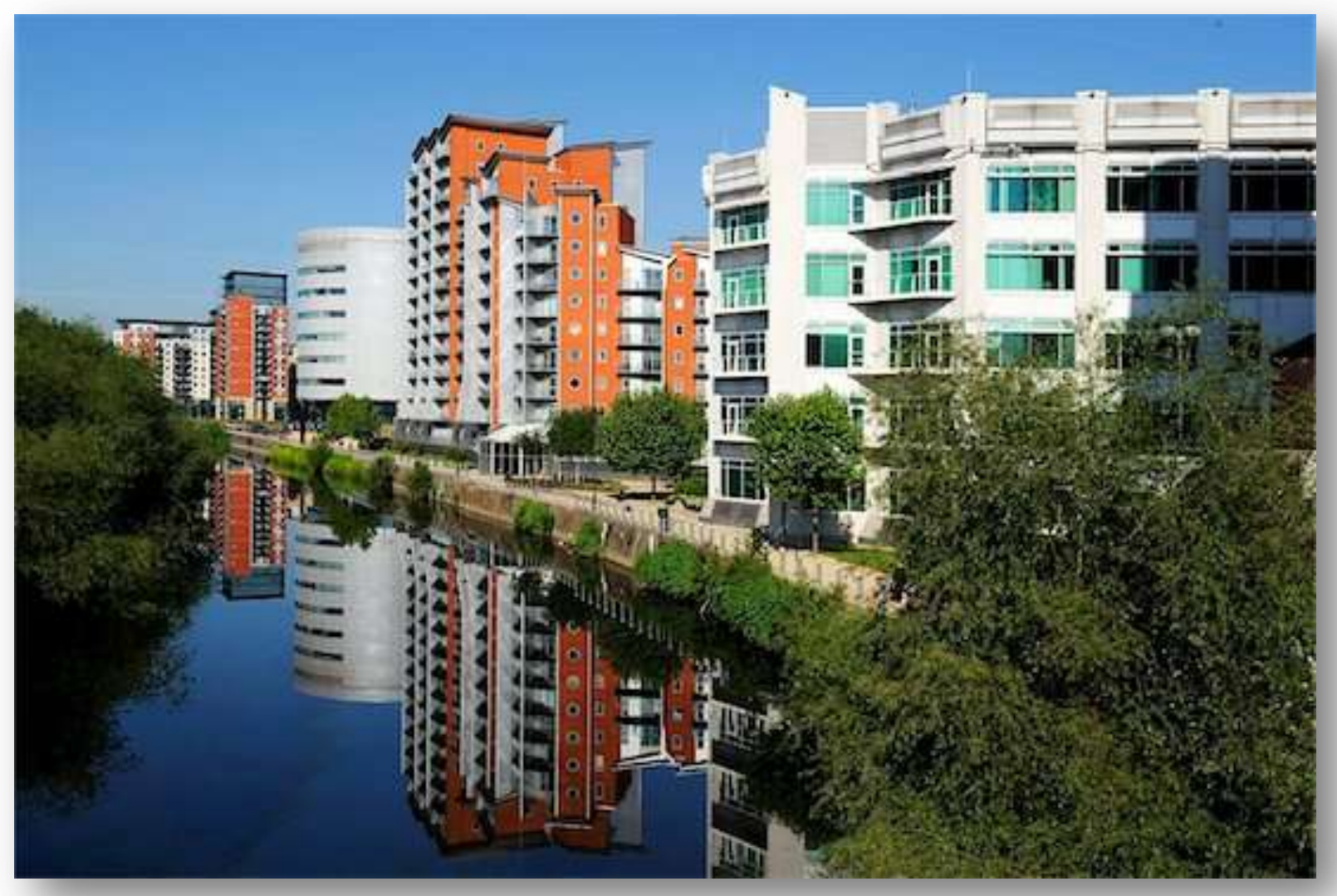

